\title{
Assessment of Self-Employment Job Opportunities Using Public and Private Organizations as Potential for Factors of Production in Case of Dire Dawa City
}

\author{
Birhane kidanu Teklehaymanot ${ }^{1}$ Getnet Girma ${ }^{2}$ Hailay Aregawi Hagos ${ }^{2}$ \\ 1.Lecturer, Dire Dawa University, Department of Management \\ 2.Lecturer, Dire Dawa University, Department of Economics \\ 2.Lecturer, Dire Dawa University, Department of Banking and finance
}

\begin{abstract}
The purpose of this study was to identify self-employment job opportunities in private and public organizations from the four factors of production viewpoints. Moreover, the study was intended to achieve the situation of job seekers (unemployed people) in Dire Dawa city, self-employment opportunities using the land, capital and enterprises in the premises of public organizations and private organizations are also analyzed. Registered unemployed people and 70 large scale organizations were investigated through questionnaire, template filling, focus group discussion and interview. Secondary data were also extracted from reports, magazines and bulletins of the organizations. $85 \%$ of the registered unemployed are not graduated from higher educations. Public and private organizations provides source of land and capital in their premises. Government owned idle land was also another source of land. Job seekers are considered as labor and their coordination and partnership creates business enterprise. Finally, the study found that 15,855 job opportunities for job seekers in the study area.
\end{abstract}

Keywords: Unemployment, job opportunity, factors of production, self employment

DOI: $10.7176 / \mathrm{EJBM} / 11-22-05$

Publication date: August $31^{\text {st }} 2019$

\section{Introduction}

The unemployment rate is becoming series problem all over the world including the developed countries. In some counties the unemployment rate reaches beyond 25 percent. For instance, there is unemployment rate of 28, 29, 25, 34, 30, 27, 50, 33 and 35 percent in Gabon, Kosovo, Mozambique, Namibia, Senegal, South Africa, Syria, Venezuela and Yemen respectively (https://en.wikipedia.org). Broussar and Tsegay (2012) identified that unemployment is significantly increasing due to expansion of educational institutions, the discrepancies over the exposure of peoples to job and the rate of job creation is low. World Bank group (2018) have also identified that Ethiopian unemployment rate reaches up to $19 \%$. Nigusse and Mulugeta (2019) also identified that Ethiopian higher education sector has experienced a remarkable expansion in the past two decades. However, the accompanying trend of growing graduate unemployment appears to have been overlooked.

As it is reported by Dire-Dawa Administration, Urban job creation and food security agency (2018), there are around 12,000 registered unemployed individuals in Dire-Dawa city. Of this around 1,800 of them are graduates from different universities and colleges in different times. Moreover, Central Statistics Agency (2018) revealed the number of unemployed people in the city reaches more than 36,000 which accounts to the unemployment rate of $25 \%$. The CSA report displayed that there are so many unemployed people who are unemployed but not registered in the districts yet.

The above evidences shows unemployment is a series issue in Ethiopia. In order to combat the rapid unemployment MSE development is under taken as key strategy. MSE sector has also been instrumental in bringing about economic transition by providing quality products and services at a reasonable price to a large number of people and by effectively using the skills and talents of a large number of people without requiring high-level of training and large sums of capital or sophisticated technology (ILO, 2008). Furthermore, MSEs are also described as the national home of entrepreneurship though which the entrepreneurs exercise their talents and natural gifts to the full extent and to attain their goals and ambitions (MoTI, 1997).

Micro and small enterprises have greater role on the reduction of the unemployment rate as well as on the growth of economy as a whole. For instance, these enterprises together contribute over 55 percent to GDP and 65 percent to total employment in developed countries as well as over 60 percent to GDP and 70 percent to total employment in developing countries (OECD, 2004). In Ethiopia, according to the 1997 sample survey conducted in 48 major towns by the Central Statistical Agency (CSA), there were around 587,644 MSEs and they absorbed 739,898 employees. As it is reported in Central Statistical Authority (2004), almost 50\% of all new jobs created in Ethiopia are attributable to MSE sector. Besides, $98 \%$ of business firms in Ethiopia are MSEs which indicated that it is the second largest employment generating next to agriculture (Aregash, 2005).

Abraham et al (2017) have identified job opportunities in Addis Ababa city. Accordingly, their study found out the opportunities in terms of existing employment opportunities (self-employment vs. hiring by private 
sectors/bureaus/offices/organizations; formal vs. informal) by sectors (manufacturing, construction, urban agriculture, trade and services) in the city; types and number of untapped alternative employment opportunities in private sectors (manufacturing, construction, urban agriculture, trade and services) and public sectors in the city.

In order to address the unemployment problems and achieve the middle income country by 2025, Ethiopia introduced the national employment policies and strategies in 2009 with three central objectives: enhancing social welfare, accelerating economic growth and achieving political stability. Besides, in line with the policies and strategies, the Ethiopian government in general and Dire Dawa city administration in particular have been making great effort to expand employment opportunities in the economy. Farther the city is identified as one of the industry corridors in Ethiopia. Building the second largest industry park in the nation is an indicator of this strategy.

Currently, the city is enriched with companies in the five sectors (manufacturing, trade, service, construction and urban agriculture). Linkage of the labor market with the existing firms is one of the excellent means to fight unemployment. Nebil et al (2010) identified that the private sector plays a tremendous role on reducing un employment via linkage in the supply chain, facilitating the plate for business through matching demand and supply etc. executing such opportunities requires detail investigation that deals with which sector, how and when can create jobs. Hence, the researchers are initiated to conduct a study with the main aim of assessing the job opportunities in the form of self employment which in turn fill the factors of production.

\section{Objective of the Study}

Generally, this study has identified self-employment job opportunities in private and public organizations from the four factors of production viewpoints. Moreover, the study was intended to achieve the following specific objectives:

- To analyze the employment situation of job seekers (unemployed people) in Dire Dawa city.

- To identify self-employment opportunities using the land, capital and enterprises in the premises of public organizations.

- To investigate the self-employment jobs using the land, capital and enterprises in private organizations.

\section{Literature Review \\ Concept of Unemployment}

The labor market, like any other markets, has both supply and demand sides. The supply side, also called the labor force or the economically active population, has two components: the employed and the unemployed (Hussmanns, 1989). The demand side on the other hand consists of jobs (filled posts) and job vacancies (unfilled posts). According to Olsson (2009), since labor is not a "normal" good, we do not have a condition where labor demand equals labor supply at equilibrium wage rate. The prevailing situation in countries around the world is instead the demand for labor is less than the supply due to the higher than equilibrium wage rate and hence there is an excess supply of labor. This gap between the supply and the demand for labor is referred to as unemployment (Abebe, 2012).

The ILO definition of unemployment, despite the fact that it has been criticized for its rigidity to accommodate peoples temporarily laid off or peoples discouraged of job prospects, comprises three conditions: being without work, currently available for work, and actively seeking for work (ILO, 2013). Therefore, unemployment refers to a situation where people who are willing and capable of working are unable to find suitable paid employment or start their own work. It is one of the macro-economic problems which every responsible government is expected to monitor and regulate. The higher would be the poverty level and associated welfare challenges.

\section{Taxonomy of Unemployment}

On the basis of the sources of unemployment, Ethiopian Economics Association (2006) identifies various types of unemployment categories. Such types of unemployment categories might be loosely grouped into those related to the state of the economic activity at a given point in time, those that reflect the inherent workings of the economy and those due to measurement errors or lack of precision in measuring unemployment. In the first category the following types of unemployment might be identified: Frictional, Structural, Seasonal, Demand deficient (cyclical) and Technological unemployment. In the second category the main categories are Classical unemployment and Marxian unemployment, and in the third sub-category Hidden unemployment, Underemployment and Disguised unemployment are the major ones.

\section{Causes of Unemployment}

Economic literature provides many explanations for the unemployment problem. Some causes blame the economic systems, and others blame the unemployed workers. Still, other theories shift the problem to external sources and shocks, or unpredictable events, and others argue that technology and labor market institutions are the causes of the unemployment problem. Other theories think the deficiency in aggregate spending and innovations are the essential factors for explaining the problem (Adil, 2011).

Like any other phenomena in economics, the ultimate state of employment/unemployment is dependent on the supply of and the demand for that factor at any given point in time. Hence, the factors that increase the supply 
of labour and the state of economic activities that influence its demand determine both the size and the type of employment/unemployment that exists. The factors that influence the supply of labour include the natural increase in the labour force or population and the labour market environment that may encourage or discourage the active population to join the labour force or not. Similarly, the demand for labour is determined by the state of the economy and the policies followed to generate the scope and the level of the economic activity underpinned by the specific technological know-how attendant at the time. That is, by how much the economy is expanding and the direction or the choice of production techniques adopted in the process (EEA, 2006).

Above all, from such many causes of unemployment, migration is the fundamental cause for unemployment problem in Dire Dawa. As a secondary city, the competitive advantage of Dire Dawa, Ethiopia is location. It is the closest large city to the port of Djibouti, making it an important transit hub for international migration via Djibouti and Somalia to the Gulf States and Europe. Whether migrants end up staying in Dire Dawa or migrating onward depends on their experiences in the city's labour market and their initial expectations. According to the 2007 census, Dire Dawa is the second largest city in Ethiopia. With an urban population of less than 20 percent, Ethiopia significantly lags behind the sub-Saharan average of 37 percent. Urbanization is, however, rapidly increasing in the country. The urban population is projected to triple from 15.2 million in 2012 to 42.3 million in 2037, growing at a rate of 3.8 percent a year. One of the factors for the growth of the urban population in Dire Dawa is rural to urban migration. Migrants constitute close to 30 percent of the city's population. Of these migrants, 45 percent come to the city from rural areas and 55 percent migrate to the city from other urban areas. This fact contributes adversely to the employment creation in Dire Dawa City.

\section{Costs of Unemployment}

Unemployment comes up with costs. According to Feldstein (1997) as cited in Abebe (2012), one who wants to analyze the costs of unemployment should start by disaggregation. The costs of unemployment can be classified broadly as private and social. The private costs of unemployment are those costs borne by the unemployed themselves. The social costs on the other hand refer to those costs to the nation at large and can be the cumulative result of private costs. Unemployment results in a waste of economic resources such as the productive labor force and thereby affect the long run growth potential of the economy. It gives rise to increased crimes, social unrest, suicides, poverty rates, alcoholism and prostitution. These evils in turn come up with a cost (cost of crime prevention) and channel resources to their prevention which rather could have been used for other developmental purposes. Unemployment may also have a scary effect. Previous spell in unemployment has a discouraging effect on future participation in the labor force, earnings and welfare in general (Abebe, 2012). Children are affected by the unemployment situation of their parents. Unemployment has an adverse effect on health and mortality via its economic, social and psychological effect on the unemployed.

\section{Conceptual Framework of the Study}

Jaafar et al (2009) presented the use of social network theory on entrepreneur's linkages development and revealed that entrepreneurs need to have strong support from the contractor, consultant, and suppliers in completing their project. Ghanem (2016) also depicted that "while strengthening public institutions responsible for implementing economic policies and important projects that provide physical and social infrastructure is necessary, it is always important to remember that it is the private sector that creates jobs and income-generating opportunities for youth". Any business activity requires labor, land, capital, and enterprise as grand pillars to deliver products and services and assure its existence and development. This study is concerned with how jobs are going to be found in which the factors are avail to create self-employment immediately. Accordingly the following conceptual framework is developed. 


\section{Land}

- Premises of public and private organization

- Free spaces(idle land) in the city

- Natural resources

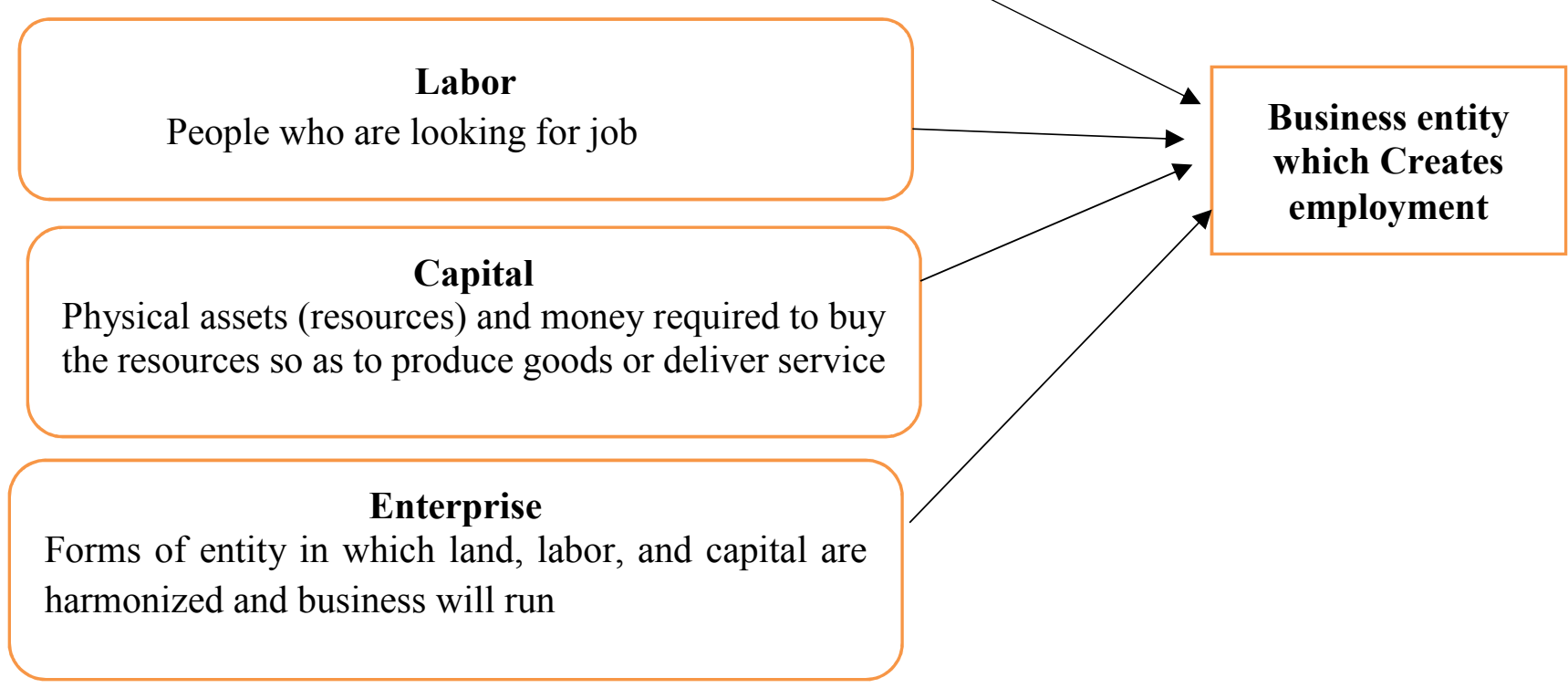

Source: Designed by researchers

\section{Research Methodology}

In this study both qualitative and quantitative data types are extracted on a cross-sectional research basis. The quantitative data deals with number of unemployed people and possible number of job opportunities (employment capacity of jobs). Types of business and working premises are expressed qualitatively. Primary and secondary sources were investigated to collect the required data. The primary sources involve premises of the companies, key informants, officials and business practitioners. Secondary sources are reports and magazines from bureau of trade, investment and industry of Dire Dawa city. Thus, primary data were collected using template filling, questionnaire, focus group discussion and interview; the secondary data were gathered through reviewing the annual reports and magazines.

The target population of the study includes Dire Dawa city Administration, urban job creation and food security agency officials and other stakeholders from other offices; both public and private large organizations found in the city; market and youth centers as well as free spaces which are considered as an opportunity for job creation. To collect the data using template filling and questionnaire, 70 large public and private organizations were selected judgmentally. These organizations were also target for interview simultaneously with the filling of the forms. Besides, focus group discussions held in 10 round (nine of them at each Administrative districts and the remaining one in the agency) were undertaken. After collecting the raw data, they were analyzed using descriptive statistical tools including table, percentage and mean particularly for data collected using template filling and questionnaire, while descriptive narration through concurrent triangulation strategy was applied to analyze the data collected through interview and focus group discussions.

\section{Data Analysis and Discussion}

\subsection{Labor Force (Job Seekers) in the Study Area}

This study have targeted the job seekers who are registered and verified as unemployed people by the agency of urban job creation and food security in Dire Dawa city administration. Therefore the result of this study pertains to the work forces that are registered as unemployed job seekers. Based on the data obtained from Dire Dawa city Administration, Urban job creation and food security agency (2018), there are 11,891 registered unemployed people in Dire Dawa city. The detail result of the obtained data is given in the table below table. 
Table 1: Distribution of Unemployed peoples in Dire Dawa city

\begin{tabular}{|c|c|c|c|c|}
\hline \multirow[t]{2}{*}{ Type } & \multirow[t]{2}{*}{ Item/variable } & \multirow[t]{2}{*}{ Category } & \multicolumn{2}{|c|}{ Frequency Distribution } \\
\hline & & & Number & Percent \\
\hline \multirow{3}{*}{ Non graduate } & \multirow[t]{3}{*}{ Gender } & Male & 4015 & 39.5 \\
\hline & & Female & 6126 & 60.5 \\
\hline & & Total & 10141 & 100 \\
\hline \multirow{24}{*}{ Graduates } & Gender & Male & 890 & 51 \\
\hline & & Female & 860 & 49 \\
\hline & & Total & 1,750 & 100 \\
\hline & \multirow[t]{5}{*}{ Education level } & Diploma & 906 & 51.70 \\
\hline & & First Degree & 809 & 46.20 \\
\hline & & Second Degree & 2 & 0.1 \\
\hline & & Missed Value & 33 & 2 \\
\hline & & Total & 1,750 & 100 \\
\hline & \multirow[t]{9}{*}{ Field of Study } & Business and economics & 527 & 30 \\
\hline & & Technology (Engineering) & 633 & 36 \\
\hline & & Health science & 209 & 12 \\
\hline & & Natural science & 55 & 3 \\
\hline & & Social science & 84 & 5 \\
\hline & & Law & 7 & 0.5 \\
\hline & & Agriculture & 39 & 2.5 \\
\hline & & Missed Value & 196 & 11 \\
\hline & & Total & 1,750 & 100 \\
\hline & \multirow[t]{7}{*}{ Year of graduation } & Before 2005 E.C & 393 & 22.5 \\
\hline & & 2006 E.C & 83 & 5 \\
\hline & & 2007 E.C & 108 & 6 \\
\hline & & 2008 E.C & 180 & 10 \\
\hline & & 2009 E.C & 207 & 12 \\
\hline & & 20010 E.C & 779 & 44.5 \\
\hline & & Total & 1,750 & 100 \\
\hline
\end{tabular}

Source: Dire Dawa city Administration, Urban job creation and food security agency (2018)

As shown from the above table $85 \%$ of the unemployed peoples are not graduated from higher education institution. This situation enforces to engage in their own business rather than looking for wage employment. There are also 1,750 people who have graduated from different educational institutions. (i.e. diploma/TVET, first degree and second degree from universities and colleges) and are looking for job. This implies that one of the factors of production (labor) is available as job seekers but still unemployed.

\subsection{Job Opportunities in the Premises of Public Organizations}

Organizations encompasses people who consumes products and services in their daily movement, demands inputs for their operation, requires channels of distribution for their products to deliver to the society. In other words, organizations can serve as a target market and source of supply for finished products to the broad market. Linking job seekers with these organizations is best strategy to minimize unemployment and support economic growth. People might employ themselves in a given business engagement through starting their own business, linkage with existing organizations (linkage: forward or backward, outsourcing and subcontracting).

The findings from the focus group discussion held with managers of public and private organizations reveals that organizations requires some services which are out of their organizational structure, but facilitates to the efficiency of their human resource and smooth running of their operations. Moreover, clients of the organizations also required services in or around the organizations. That is employees and clients of the organizations needs clean and attractive and secured work premises, access to facilities cafeterias and restaurants, secretarial works (writing, photocopy, printing and the like). To execute such issues organizations outsources external parties to perform the jobs listed in the table below.

Most of manufacturing organizations located far from the center of the city where there is no easy access services to their needs and wants. This affects the motion time of employees and efficiency becomes adversely affected. To overcome such kind of difficulties organizations have prepared facilities for café and restaurants. This is a great opportunity for those who have commitment and skill but lacks financial capability to set the service in the general market. In the survey various public organizations such as administrative offices of governmental bureaus, youth centers, sport fields, market centers, schools universities TVET colleges, hospitals, and bus station located in Dire Dawa city were incorporated to identify the potential job opportunities through self-employment 
within their respective premises.

Table 2: Job opportunities in the premises of government offices, youth centers and Dire Dawa stadium

\begin{tabular}{|c|c|c|c|c|c|c|}
\hline Organization & Number & Job title & $\begin{array}{l}\text { Entity to be } \\
\text { engaged }\end{array}$ & $\begin{array}{l}\text { No of } \\
\text { entities }\end{array}$ & $\begin{array}{l}\text { Number } \begin{array}{r}\text { of } \\
\text { people per } \\
\text { entity }\end{array} \\
\end{array}$ & $\begin{array}{l}\text { Total no } \\
\text { of people }\end{array}$ \\
\hline \multirow[t]{2}{*}{$\begin{array}{l}\text { government } \\
\text { office }\end{array}$} & \multirow[t]{2}{*}{9} & $\begin{array}{l}\text { Stationary and } \\
\text { secretarial works }\end{array}$ & Partnership & 9 & 5 & 45 \\
\hline & & Café and restaurant & Partnership & 9 & 5 & 45 \\
\hline \multirow[t]{6}{*}{ Youth centers } & \multirow[t]{6}{*}{9} & Shower service & Partnership & 9 & 5 & 45 \\
\hline & & Internet café & Partnership & 9 & 5 & 45 \\
\hline & & $\begin{array}{l}\text { Cafeteria }+ \text { play } \\
\text { station }\end{array}$ & Partnership & 9 & 5 & 45 \\
\hline & & Beauty salon & Partnership & 9 & 5 & 45 \\
\hline & & Barber shop & Partnership & 9 & 5 & 45 \\
\hline & & Shoe cleaning & Partnership & 9 & 5 & 45 \\
\hline \multirow[t]{3}{*}{$\begin{array}{ll}\text { Dire } & \text { Dawa } \\
\text { stadium } & \end{array}$} & \multirow[t]{3}{*}{1} & $\begin{array}{l}\text { Retail shops for } \\
\text { products of different } \\
\text { factories }\end{array}$ & Partnership & 60 & 5 & 300 \\
\hline & & Parking & partnership & 1 & 20 & 20 \\
\hline & & Selling Ticket & partnership & 1 & 20 & 20 \\
\hline Total & & & & & & 700 \\
\hline
\end{tabular}

Source: Questionnaire Survey (2019)

Offices of the government have community (collection of persons as employees and customers). These people are expected to consume coffee, tea, fast food, mineral water and so on. Farther they may need service like writing applications, photocopy and other secretarial services. In line to this, the above table shows that the premises of administration office, job opportunities for 10 entities which include 5 members can be created. The above table also indicates business types that youth can engage in the premises of the youth centers and sport fields. Both are owned by sport and youth affairs commission. As per the investigations made, most of the youth centers are not functional. With regard to their potential job opportunities, the result of the survey shown that at these centers 270 job opportunities is identified. Furthermore, Dire Dawa stadium has 60 business rooms which are ready for supermarkets, cafeterias, restaurants, fruit and juice hose and other retailing shops. In each of these rooms is also expected to create for at least 5 peoples each which sums 300 peoples. Parking and selling tickets are also related business around the stadium which are expected to create for at least 40 job seekers. Hence, via dealing with the sport commission, it enables to create jobs for more than 610 people.

The above paragraph indicates that using the premises of public servant offices and other government owned institutions as business areas enables job seekers to get the source of land.

Table 3: Job opportunities in the premises of schools, TVET, University and hospitals and health centers

\begin{tabular}{|c|c|c|c|c|c|c|}
\hline Organization & Number & Job title & $\begin{array}{l}\text { Entity to be } \\
\text { engaged }\end{array}$ & $\begin{array}{l}\text { No of } \\
\text { entities }\end{array}$ & $\begin{array}{l}\text { Number of } \\
\text { people per } \\
\text { entity }\end{array}$ & $\begin{array}{l}\text { Total } \\
\text { no of } \\
\text { people }\end{array}$ \\
\hline \multirow[t]{2}{*}{$\begin{array}{l}\text { Secondary } \\
\text { schools }\end{array}$} & 29 & $\begin{array}{l}\text { Stationary and } \\
\text { secretarial works }\end{array}$ & Partnership & 29 & 5 & 145 \\
\hline & & Café and restaurant & Share .co & 29 & 5 & 145 \\
\hline Primary schools & 27 & Mini grocery & Partnership & 27 & 5 & 115 \\
\hline \multirow{7}{*}{$\begin{array}{l}\text { Dire Dawa } \\
\text { University }\end{array}$} & \multirow[t]{7}{*}{1} & super market & Partnership & 2 & 5 & 10 \\
\hline & & $\begin{array}{l}\text { Male and female } \\
\text { beauty salons }\end{array}$ & Partnership & 8 & 5 & 400 \\
\hline & & 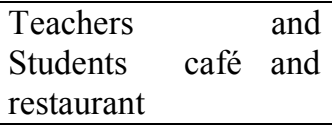 & Partnership & 3 & 20 & 60 \\
\hline & & $\begin{array}{l}\text { Teachers \& recreation } \\
\text { center (game station) }\end{array}$ & Partnership & 1 & 5 & 5 \\
\hline & & $\begin{array}{ll}\text { recreation } & \text { center } \\
\text { (game station) }\end{array}$ & Partnership & 2 & 20 & 40 \\
\hline & & $\begin{array}{ll}\begin{array}{l}\text { Stationary } \\
\text { printing service }\end{array} & \text { and } \\
\end{array}$ & Partnership & 5 & 5 & 25 \\
\hline & & Gymnasium service & Partnership & 1 & 5 & 5 \\
\hline
\end{tabular}




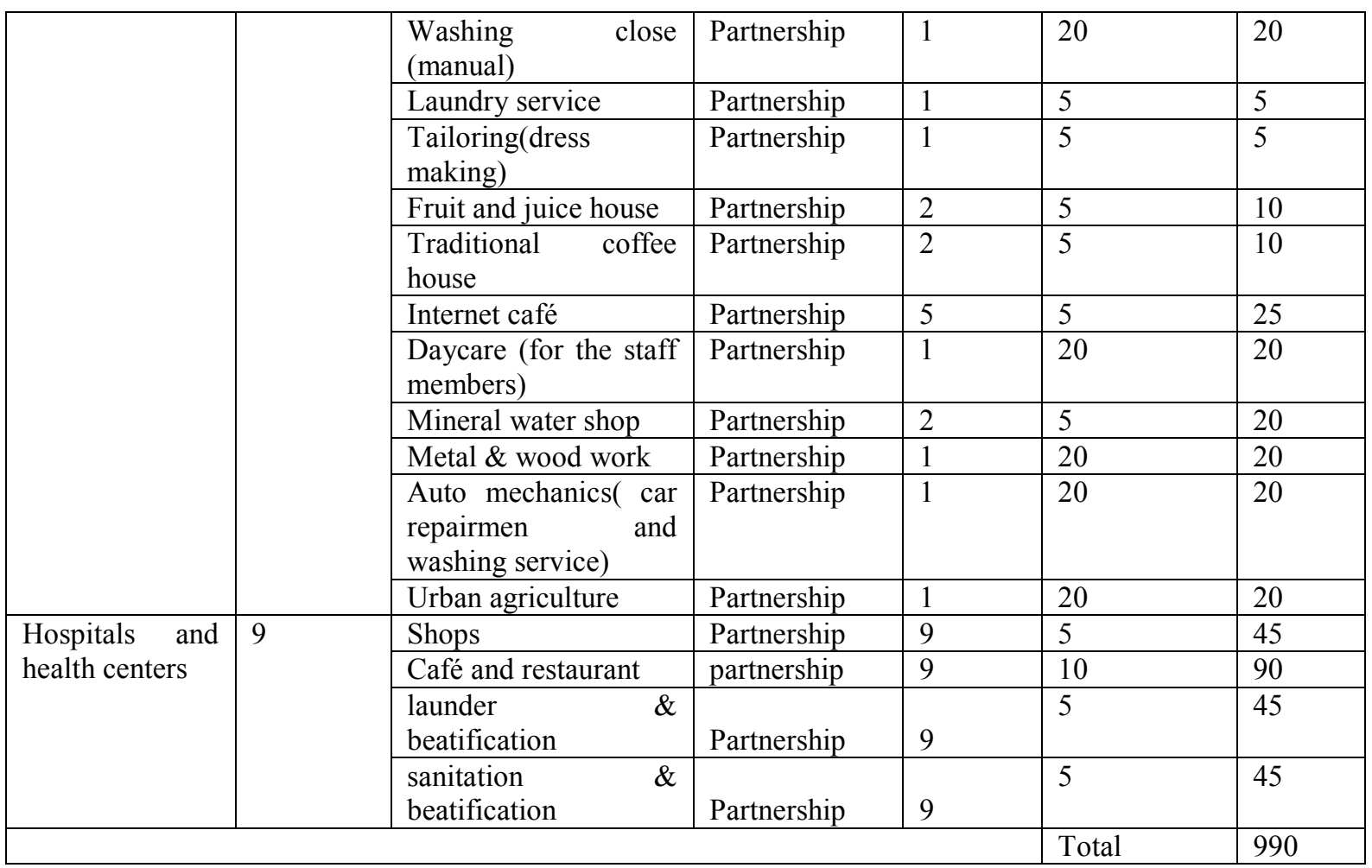

Source: Questionnaire Survey (2019)

An education center includes Kindergartens, primary schools, high schools, colleges and Dire Dawa University. These centers involve students who consume fast foods and beverages, utilize stationary materials, photocopy, beauty salon, etc. It is not only the students, some of the educational centers like Dire Dawa Comprehensive secondary school have place for min-shops and service centers to the community in its surrounding like the Sabina highs school did. This may create job for around 30 people. Further Dire Dawa comprehensive secondary school has free space which is suitable for urban agriculture and can accommodate more than 20 youths in this sector only. As table 3 shows, government owned primary and secondary schools which are around 56 in number are potential areas for more than 450 to engage in business works. Further Dire Dawa comprehensive secondary school has free space which is two tables for urban agriculture and can accommodate more than 20 youths in this sector. Dire Dawa University has around 12,000 students and more than 2,000 employees. This shows that there are significant potential consumers of goods and services in the compound. The university also considers the compound and its surrounding is potential business area. It develops a work function of income generation in directorate level. The university has built football field which includes 10 rooms which are sweet able for minimarket, barber shop, beauty salon, stationary and photocopy shop, juice house, fast food production and sales etc.

The university has only one staff lounge. Staff of the university demands more restaurant, café, recreation center (like game station), day care center for their children, supplies of consumer goods in less price than the general market in the city, shoe cleaning, etc. farther, the university owns 41 vehicles and is expected to expand in the coming time. This creates a potential of outsourcing mini garage for maintenance. Universities are allowed to generate their own income through the proclamation and possible business areas are identified by income generation in directorate of the university as wood work, general metal work and urban agriculture. These potentials of business serve only for the community in the campus. The university can also provide mini shops over its premises which can serve the community in the surround. With this regard the university can create jobs for more than 385 youths.

The above table also shows job opportunities in government owned Hospitals, and health centers. This study has targeted government owned health cares for the reason that there is possibility of aligning the centers with the strategy of MSE development. Some of the health centers (e.g. Dilchora hospital, sabian hospital) are currently occupied with some of the business listed above (e.g. Shops, cafeteria). As per the Ethiopia's MSE development strategy (2011), people who have sufficient wealth to be competent in the general business environment are supposed to leave the space for those of not having wealth and business experience. These institutions are areas where peoples' trafficking is high. Using the potential within and their surrounding for business activities creates jobs for more than 225 youths. As per the result of interview held with directors of the hospitals and health centers, they have confirmed that these institutions are willing to welcome youth entrepreneurs to do business activities in 
the compound of the health centers.

Table 4: Job opportunities in the premises of Bus Station and other public organizations

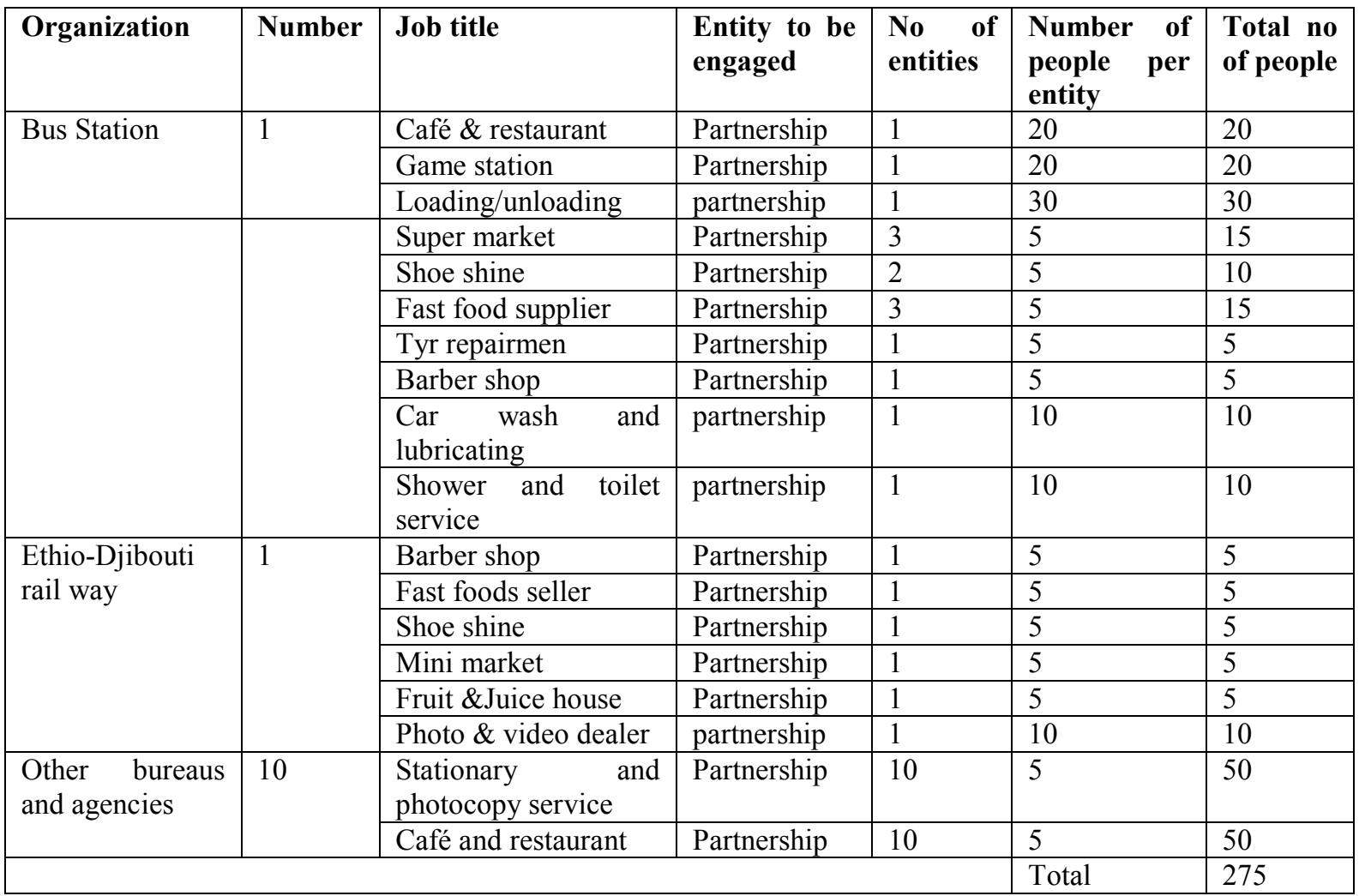

Source: Questionnaire Survey (2019)

Bus station and customs authority are similar that they accommodate a mass of people during their operation. They are areas where drivers, drivers' assistants, travelers/dealers, temporary and permanent workers are avail. Buses, heavy tracks and other vehicles are also available in and around these areas. People requires service, vehicles also requires different treatments. These actions are business potentials for job seekers. Harmonizing people with people resources leads to attractive economic activities around the area. The new Ethio-Djibouti rail way which is established in recent time has also free space around its station. as per the focus group discussion with the management team of the rail way (Dire Dawa station) have confirmed that there is a free space which can be used for different business activities. The area is accessible for travelers and community of Dire Dawa city. It can also serve as recreation center for weeding and other group enjoyments. In general the above table shows the capacity of at least 235 youth to engage in different businesses for their employment.

In addition to this there are different Bureaus located in different places of the city. Some of them are bureau of health care, mayor's office, bureau of education, bureau of youth and sport affairs, etc. These organizations are located in at least 10 cites of the city and are serving the community. Since there is peoples' movement within and around these offices, they may also be potential areas for business works, like in the premises of the administrative districts. In other words, these places can create jobs for at least 5 people in each place which sums 100 peoples. This indicates that if these offices arrange their premises it is possible to create job for more than 360 youths. This number is calculated with the assumption that all the jobs are going to be done in a group (partnership) base and every member of each group will have a direct engagement as a labor force of their own business. i.e. they will not hire other employees like casher, servant, cooker etc.

\subsection{Job Opportunities in the Premises of Private Organizations}

Like that of the government owned Schools and higher educational institutions, private owned Schools and colleges are full of people who consume products and services. There are 147 Schools (kg and, primary and secondary) and 4 privet colleges. Most of manufacturing organizations located far from the center of the city where there is no easy access services to their needs and wants. This affects the motion time of employees and efficiency becomes adversely affected. To overcome such kind of difficulties organizations have prepared facilities for café and restaurants. This is a great opportunity for those who have commitment and skill but lacks financial capability to set the service in the general market. 
Table 5: job opportunities in the premises of Private organizations

\begin{tabular}{|l|l|l|l|l|l|l|}
\hline School/college & Number & Business type & Entity & $\begin{array}{l}\text { Number of } \\
\text { entity }\end{array}$ & $\begin{array}{l}\text { No. } \\
\text { people/ } \\
\text { entity }\end{array}$ & $\begin{array}{l}\text { Total no. } \\
\text { of people }\end{array}$ \\
\hline $\begin{array}{l}\text { Private primary } \\
\text { Schools }\end{array}$ & 38 & Cafeteria & partnership & 38 & 5 & 190 \\
\hline Kg Schools & 109 & Mini grocery & partnership & 109 & 45 & 545 \\
\hline College & 4 & Mini grocery & Partnership & 4 & 5 & 20 \\
\hline $\begin{array}{l}\text { Manufacturing } \\
\text { companies }\end{array}$ & 15 & $\begin{array}{l}\text { Café and } \\
\text { restaurant Partnership }\end{array}$ & 15 & 10 & 150 \\
\hline $\begin{array}{l}\text { Financial and } \\
\text { institutions }\end{array}$ & 10 & $\begin{array}{l}\text { Café } \\
\text { restaurant artnership }\end{array}$ & 10 & 10 & 100 \\
\hline $\begin{array}{l}\text { Other private } \\
\text { organizations }\end{array}$ & 15 & $\begin{array}{l}\text { Café } \\
\text { restaurant }\end{array}$ & $\begin{array}{l}\text { Partnership } \\
\text { beauty salon }\end{array}$ & 15 & 10 & 150 \\
\hline $\begin{array}{l}\text { Hotels and women } \\
\text { Total Partnership }\end{array}$ & 5 & 10 & 5 & 50 \\
\hline
\end{tabular}

Source: Questionnaire Survey (2019)

If job seekers are organized and willing to engage in food processing activities like preparing take away juice, packed juice, cookies, chocolate chips, chips, mineral water and other. There is possibility of creating jobs for more than 755 individuals. Each of the manufacturing organization is found to accommodate at least 10 people as workers in the café and restaurant to be actualized in the compound of the company. Around 15 manufacturing organizations show their willingness to outsource the café and restaurant in their compound.

In addition to this, financial institution like banks and insurances requires tea and coffee suppliers. Except the head quarter of commercial Bank of Ethiopia, other institutions have no organized place for cafeteria and restaurant. Rather they are utilizing informal suppliers, or other service renders in their surroundings. According to the interviews with labor representatives of the financial institutions they are happy if there are organized service renders in consensus with the institutions. Since the branches of the institutions are located scattered throughout the city, service renders can be assigned in cluster approach. for example for the financial institutions around the place called Seido (local name) could be considered as one cluster, financial institutions around the place called Meskelegna (local name) could be considered another cluster and the like. Through this approach it is possible to create job for around 100 people in 10 clusters. It is also shown that 200 job opportunities that can be created in hotels and other private organizations using the above similar way.

5.4. Job Opportunities through Linkage

Table 6: Job opportunities through supplying input to manufacturing companies

\begin{tabular}{|c|c|c|c|c|c|c|}
\hline Supply & Source & $\begin{array}{l}\text { Company to be } \\
\text { supplied for }\end{array}$ & Entity & $\begin{array}{l}\text { No of } \\
\text { entity }\end{array}$ & $\begin{array}{l}\text { No of } \\
\text { members/ } \\
\text { entity }\end{array}$ & $\begin{array}{l}\text { Total } \\
\text { memb } \\
\text { ers }\end{array}$ \\
\hline $\begin{array}{l}\text { Input for furniture } \\
\text { manufacturing like } \\
\text { semi processed wood, } \\
\text { and other industrial } \\
\text { products (supplies) }\end{array}$ & $\begin{array}{l}\text { Local Wood } \\
\text { processing } \\
\text { companies, importers }\end{array}$ & $\begin{array}{l}\text { Furniture } \\
\text { manufacturers }\end{array}$ & $\begin{array}{l}\text { Partnershi } \\
\mathrm{p}\end{array}$ & 5 & 5 & 25 \\
\hline $\begin{array}{l}\text { Supplier of Spare parts } \\
\text { for machineries }\end{array}$ & $\begin{array}{l}\text { Importers, local } \\
\text { producers like the } \\
\text { oldest Ethio- Djibouti } \\
\text { rail way etc }\end{array}$ & $\begin{array}{l}\text { Factories, } \\
\text { \&construction } \\
\text { companies, }\end{array}$ & $\begin{array}{l}\text { Partnershi } \\
\mathrm{p}\end{array}$ & 2 & 5 & 10 \\
\hline Wheat supply & $\begin{array}{l}\text { Collecting from } \\
\text { farmers }\end{array}$ & $\begin{array}{l}\text { Flour factories, } \\
\text { bakeries, and the } \\
\text { community }\end{array}$ & $\begin{array}{l}\text { Partnershi } \\
\text { ps }\end{array}$ & 5 & 20 & 100 \\
\hline Sawdust supply & $\begin{array}{l}\text { Collecting from } \\
\text { furniture producers }\end{array}$ & $\begin{array}{l}\text { To nail factories } \\
\text { in Dire Dawa, } \\
\text { and other cities }\end{array}$ & $\begin{array}{l}\text { Partnershi } \\
\mathrm{p}\end{array}$ & 2 & 5 & 10 \\
\hline $\begin{array}{l}\text { Raw materials of } \\
\text { cement production } \\
\text { (e.g. limestone ... }\end{array}$ & $\begin{array}{l}\text { Available in and } \\
\text { around the city }\end{array}$ & Cement factories & $\begin{array}{l}\text { Partnershi } \\
\mathrm{p}\end{array}$ & 5 & 20 & 100 \\
\hline \multicolumn{6}{|l|}{ Total } & 245 \\
\hline
\end{tabular}

Source: Questionnaire Survey (2019) 
The above table shows how youth can involve in the trade sector via the consideration of the supply chain of manufacturing industries in the city. Due to the reason that Dire Dawa city is one of the industry corridors in Ethiopia there is huge capacity to accommodate suppliers of industrial input. But more of the inputs (like raw materials, machineries etc.) are imported goods and require huge capital which is beyond the capability of MSEs in Ethiopia. With this conception this study has identified the possible business areas where MSEs can perform as suppliers to the industries. Currently, the government of Ethiopia is aggressively striving to replace the imports of wheat with local agriculture. This is great opportunity for people who are willing to engage in collecting whet from farmers and redistributing to food processing industries and the community as a whole.

Furniture manufacturing centers are tremendously expanding in Dire Dawa. Despite of this expansion there is scarcity of raw materials and supplies required. This study found that people may engage in wood semi processing, purchasing locally produced raw materials of furniture and redistributing to manufacturers of furniture, purchasing supplies from importers and redistributing. Such kind of trade activities might be subject for completive rivalry. But due to the governmental support for MSEs (like working premises which minimizes the cost of leasing, creating linkage with direct importers which in turn minimizes cost of the value chain, VAT exemption etc.) enables to excel in cost leadership strategy and become competent in the area.

Sawdust is used as a polishing material for nail manufacturing. Nail producer in Dire Dawa city is currently purchasing sawdust from Addis Ababa due to the absence of supplier from Dire Dawa. Even though there is only one nail manufacturer in the city collecting sawdust from the furniture producers and redistributing to nail producers in Dire Dawa and expanding the market to other cities is also another potential job area. Generally, back ward chain of currently functioning manufacturing industries in Dire Dawa city can create job for at least 245 peoples in the form of Micro and Small scale being suppliers. This indicates industrial expansion and new entrants can also create more jobs in their supply chain.

Table 7: job opportunities via Using/selling output of manufacturing companies

\begin{tabular}{|c|c|c|c|c|c|c|}
\hline Linkage & Source & $\begin{array}{l}\text { Target } \\
\text { market }\end{array}$ & Entity & $\begin{array}{l}\text { No of } \\
\text { entity }\end{array}$ & $\begin{array}{l}\text { No of } \\
\text { members/entity }\end{array}$ & $\begin{array}{l}\text { Total } \\
\text { members }\end{array}$ \\
\hline $\begin{array}{l}\text { Distributing } \\
\text { products as } \\
\text { wholesaler }\end{array}$ & $\begin{array}{l}\text { Mineral water } \\
\text { producers, soap and } \\
\text { detergent, food } \\
\text { complex, nail factory, } \\
\text { flour factory, }\end{array}$ & $\begin{array}{l}\text { Retailers in } \\
\text { every } \\
\text { district }\end{array}$ & Partnership & 100 & 5 & 500 \\
\hline $\begin{array}{l}\text { Reselling by } \\
\text { products } \\
\text { (defective } \\
\text { bottles, cattle } \\
\text { meal }\end{array}$ & $\begin{array}{lr}\begin{array}{l}\text { Mineral } \\
\text { producers, }\end{array} & \text { water } \\
\text { complex, } & \text { flour } \\
\text { factories } & \end{array}$ & $\begin{array}{l}\text { Recyclers, } \\
\text { Urban } \\
\text { agriculture, }\end{array}$ & Partnership & 4 & 5 & 20 \\
\hline \multicolumn{5}{|l|}{ Total } & \multicolumn{2}{|l|}{520} \\
\hline
\end{tabular}

Source: Questionnaire Survey (2019)

Dire Dawa city has multiple manufacturing industries (source). Some of these are addressed by this study in order to investigate the possibility of job creation through linkage. Six mineral water producers are investigated and they can create jobs for at least 9 wholesalers each. Therefore, one wholesaler for each factory in each administrative district can work. This in turn enables to have 54 wholesalers in the city. Each shop is assumed to be done in partnership base with a group of 5 persons in each partnership. Farther we flour factories, food complex, nail producer and soap \& detergent factories are assumed to have 9 wholesalers in the 9 administrative districts. This enables to create jobs for at least 500 persons. In addition to this by-products and defective products of some manufacturing companies are used as an input for other process. Among them byproducts of food complex producers can be meal for cattle and can be sold for those who are engaged in urban agriculture. Mineral water producers dispose defective bottles in a huge amount. This defective bottle plus collecting arranging used bottles of mineral water for recycling is another job area. In general more than 520 people can be engaged in the current existing forward supply chain of the manufacturing industry. 
Table 8: Job opportunities through linkage with service rendering organizations

\begin{tabular}{|c|c|c|c|c|c|c|}
\hline Supplies & Source & $\begin{array}{l}\text { Target } \\
\text { market }\end{array}$ & Entity & $\begin{array}{l}\text { No of } \\
\text { entity }\end{array}$ & $\begin{array}{l}\text { No of } \\
\text { members/entity }\end{array}$ & $\begin{array}{l}\text { Total } \\
\text { members }\end{array}$ \\
\hline $\begin{array}{l}\text { Supplier of } \\
\text { vegetables, and } \\
\text { fruit }\end{array}$ & $\begin{array}{l}\text { Melkajebdu } \\
\text { agriculture, Yerer } \\
\text { agriculture, tony } \\
\text { agriculture, and } \\
\text { from villages } \\
\text { around the city }\end{array}$ & $\begin{array}{l}\text { Hotels and } \\
\text { restaurants, } \\
\text { juice house }\end{array}$ & Partnership & 3 & 20 & 60 \\
\hline $\begin{array}{l}\text { Semi processed } \\
\text { chicken, meat, } \\
\text { better, and } \\
\text { other animal } \\
\text { products }\end{array}$ & $\begin{array}{l}\text { Urban agriculture } \\
\text { businesses in and } \\
\text { around the city. }\end{array}$ & $\begin{array}{l}\text { Hotels and } \\
\text { restaurants, } \\
\text { cafeterias }\end{array}$ & partnership. & 3 & 20 & 60 \\
\hline $\begin{array}{l}\text { Collecting and } \\
\text { selling } \\
\text { byproducts of } \\
\text { hotels and } \\
\text { restaurants }\end{array}$ & $\begin{array}{l}\text { Hotels } \\
\text { restaurants, juice } \\
\text { house }\end{array}$ & $\begin{array}{l}\text { Urban } \\
\text { agriculture }\end{array}$ & Partnership & 1 & 20 & 20 \\
\hline \multicolumn{6}{|l|}{ Total } & 140 \\
\hline
\end{tabular}

Source: Questionnaire Survey (2019)

As displayed in the above table the possible job alternatives in this regard are collecting the raw inputs, semi processing, packing and organizing are some of the activities to be held by those who engaged in this business. With the assumption that all members of the partnership will actively participate in the business process each team requires 20 people. Accordingly, 140 people can be engaged in such business initially.

Table 9: Job opportunities through linkage with urban agriculture

\begin{tabular}{|c|c|c|c|c|c|c|}
\hline Job title & Sources & $\begin{array}{l}\text { Target } \\
\text { market }\end{array}$ & Entity & $\begin{array}{l}\text { No of } \\
\text { entities }\end{array}$ & $\begin{array}{l}\text { No. of } \\
\text { persons } \\
\text { per } \\
\text { entity }\end{array}$ & $\begin{array}{l}\text { Total } \\
\text { no of } \\
\text { persons }\end{array}$ \\
\hline $\begin{array}{l}\text { Supplying cattle, } \\
\text { and poultry meal }\end{array}$ & 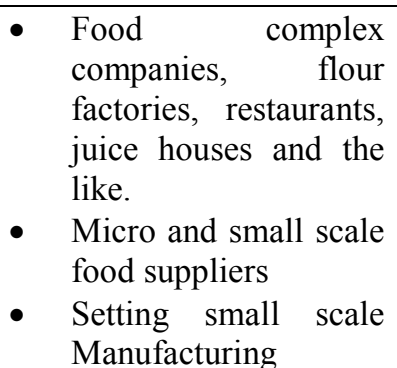 & $\begin{array}{l}\text { Urban } \\
\text { agriculture } \\
\text { businesses }\end{array}$ & partnership & 5 & 20 & 100 \\
\hline $\begin{array}{l}\text { Vegetables } \\
\text { supplying }\end{array}$ & & $\begin{array}{l}\text { Urban and } \\
\text { rural } \\
\text { agriculture }\end{array}$ & Partnership & 5 & 5 & 25 \\
\hline $\begin{array}{l}\text { Retailing outputs } \\
\text { of dairy and } \\
\text { poultry farming }\end{array}$ & Urban and rural agriculture & Community & partnership & 20 & 10 & 200 \\
\hline $\begin{array}{l}\text { Consultancy and } \\
\text { professional } \\
\text { service }\end{array}$ & $\begin{array}{l}\text { Graduates } \\
\text { universities in veterinary } \\
\text { science, animal science, } \\
\text { and related fields }\end{array}$ & $\begin{array}{l}\text { Urban } \\
\text { agriculture }\end{array}$ & partnership & 5 & 10 & 50 \\
\hline $\begin{array}{l}\text { Collecting, } \\
\text { processing and } \\
\text { reselling compost }\end{array}$ & Dairy and poultry farms & & partnership & 2 & 10 & 20 \\
\hline fruit wholesaler & & & Partnership & 3 & 5 & 15 \\
\hline $\begin{array}{l}\text { Vegetable } \\
\text { wholesaler }\end{array}$ & & & Partnership & 3 & 5 & 15 \\
\hline \multicolumn{6}{|l|}{ Total } & 225 \\
\hline
\end{tabular}

Source: Questionnaire Survey (2019)

Like any other sector urban agriculture requires both back ward (inbound) and forward (out bound) linkages 
with MSEs to facilitate its business process. As shown in table 3.13 above, the most common urban agriculture practice in the city are dairy farming and poultry. These cattle and poultry require food (meal) medical treatment and other proactive cares. The success of commercial livestock farming largely depends on the continuous supply of good quality nutritious feeds. Poultry feed industry, dependent on the sound growth of poultry has a great untapped potential in Dire Dawa. Any individual or a group of individuals can start cattle and poultry feed manufacturing business as small and large scale basis. In addition, you can also start only cattle feed or only poultry feed manufacturing. Manufacturing is not the only alternative to execute the business. However collecting food processing companies is another alternative. The manufacturing process is simple. Finally, you can procure the raw materials from the local wholesale market.

\subsection{Job Opportunities through Subcontracting}

Table 10: Job opportunities through subcontracting

\begin{tabular}{|c|c|c|c|c|c|}
\hline Area & Job title & $\begin{array}{l}\text { Entity to be } \\
\text { engaged }\end{array}$ & $\begin{array}{l}\text { No of } \\
\text { entities }\end{array}$ & $\begin{array}{l}\text { Number of people } \\
\text { per entity }\end{array}$ & $\begin{array}{l}\text { Total no of } \\
\text { people }\end{array}$ \\
\hline \multirow{9}{*}{$\begin{array}{l}\text { Construction } \\
\text { bureau }\end{array}$} & special contractors & Partnership & 5 & 5 & 25 \\
\hline & sub-contractors & Partnership & 5 & 5 & 25 \\
\hline & material suppliers & Partnership & 5 & 5 & 25 \\
\hline & machinery suppliers & Partnership & 5 & 5 & 25 \\
\hline & Consultant & Partnership & & 5 & 25 \\
\hline & metal work & Partnership & 5 & 5 & 25 \\
\hline & wood work & Partnership & 5 & 5 & 25 \\
\hline & electrical installation & Partnership & 5 & 5 & 25 \\
\hline & sanitation works & Partnership & 5 & 5 & 25 \\
\hline \multirow{10}{*}{$\begin{array}{l}\text { Road } \\
\text { authority }\end{array}$} & Dish repairmen & partnership & 2 & 5 & 10 \\
\hline & bridge repairmen & partnership & 5 & 5 & 25 \\
\hline & sub base work & partnership & 12 & 5 & 60 \\
\hline & $\begin{array}{l}\text { collecting materials during } \\
\text { the end of rad constriction }\end{array}$ & partnership & 7 & 5 & 35 \\
\hline & dish cleaning & partnership & 18 & 5 & 90 \\
\hline & URAP & partnership & 10 & 5 & 50 \\
\hline & cobblestone supplier & Partnership & 3 & 20 & 60 \\
\hline & car wash & partnership & 1 & 5 & 5 \\
\hline & $\begin{array}{l}\text { sand and crashed stone } \\
\text { suppliers }\end{array}$ & Partnership & 3 & 20 & 60 \\
\hline & café and restaurant & partnership & 1 & 5 & 5 \\
\hline \multirow{5}{*}{$\begin{array}{l}\text { Housing } \\
\text { development } \\
\text { agency }\end{array}$} & precast beam production & Partnership & 5 & 5 & 25 \\
\hline & terrazzo production & Partnership & 5 & 5 & 25 \\
\hline & slab block producer & Partnership & 5 & 5 & 25 \\
\hline & electric installation & Partnership & 5 & 5 & 25 \\
\hline & Sanitation work & Partnership & 5 & 5 & 25 \\
\hline $\begin{array}{l}\text { Ethiopia elec. } \\
\text { Supp }\end{array}$ & $\begin{array}{l}\text { installing and repairing } \\
\text { electric distribution lines }\end{array}$ & Partnership & 3 & 50 & 150 \\
\hline $\begin{array}{l}\text { Sanitation and } \\
\text { beautification }\end{array}$ & Manufacturing co. & Partnership & 15 & 10 & 150 \\
\hline $\begin{array}{l}\text { Janitor and } \\
\text { security guard }\end{array}$ & $\begin{array}{l}\text { Manufacturing } \\
\text { organizations hotels, shops, } \\
\text { market centers etc. }\end{array}$ & Partnership & 20 & 10 & 200 \\
\hline $\begin{array}{l}\text { Loading and } \\
\text { unloading }\end{array}$ & Manufacturing co. & Partnership & 15 & 30 & 450 \\
\hline \multicolumn{5}{|l|}{ Total } & 1,700 \\
\hline
\end{tabular}

Source: Questionnaire Survey (2019)

As shown in table 3.9 above youths who have capability of doing the listed jobs are beneficiaries through owning a business entity and taking subcontract from the institutions listed. As per their result of interview with the head of construction bureau of the city, existing contractors have responsibility of enriching emerging 
contractors through providing them with sub contracts. This is one of the criterion while competing in their bids. The above quantity is not sufficient for the fast growing construction industry in the city. Rather it displays the quick job creation for current period. Road authority and housing agency have construction, maintenance activities held by their selves. They utilize different suppliers and sub-contractors to execute their projects. With this regard it is possible to create jobs for more than 900 people.

Organizations, especially these involved in manufacturing requires cleaning and beautification of their compound and their surroundings, keeping safety and security, to enhance the satisfaction and loyalty of their work force and to keep peaceful and healthy working environment. In addition to this, business areas in different places of the city require organized security guards for their surrounding respectively. Therefore, people can be organized in a team of 10 or more and have legal agreements with those who need the security guard sanitation and beautification service. With this approach it is possible to create job for more than 350 people. Loading and unloading is also another job area in the manufacturing organizations. It is found that there is no formal approach to accommodate laborers of loading and unloading. Less wage rates, high turnover and conflicts among employees and employers are some problems due to unorganized approach of engaging in such jobs. Making partnership based and having formal engagements through effective negotiation for wage rate, work load, working shifts can provide effective solution for the problems. This in turn can create for at least 450 job seekers.

\subsection{Job Opportunities at Free Spaces}

Open spaces are idle places which are currently available in different administrative districts of the city. These free spaces create an opportunity for the access of job temporarily and permanently. Idle land space should be utilized in temporary manner in quarterly, semiannual and annual bases to create jobs for unemployed people. Mobile shops, fast food production, and services like beauty salon service, electronics maintenance, and mini-garage are some of the possible jobs over the free space.

Table 11: Job opportunities in open spaces in DDA, Administrative district Two

\begin{tabular}{|c|c|c|c|c|c|c|}
\hline No & Name of the open space & $\begin{array}{l}\text { Location } \\
\text { (local } \\
\text { name) } \\
\end{array}$ & $\begin{array}{l}\text { Area } \\
\text { in } \\
(\mathrm{M} 2)\end{array}$ & $\begin{array}{l}\text { List of possible } \\
\text { job alternatives }\end{array}$ & $\begin{array}{l}\text { Possible } \\
\text { Entity }\end{array}$ & $\begin{array}{l}\text { Number of } \\
\text { people/entit } \\
\mathbf{y}\end{array}$ \\
\hline \multirow[t]{3}{*}{1} & \multirow[t]{3}{*}{$\begin{array}{l}\text { In the compound of trade center } \\
\text { buildings in administrative } \\
\text { district two }\end{array}$} & \multirow[t]{3}{*}{ Sabian } & & $\begin{array}{l}\text { retail trade with } \\
\text { different } \\
\text { specialization }\end{array}$ & $\begin{array}{l}\text { Sole } \\
\text { proprito } \\
\text { rship }\end{array}$ & 100 \\
\hline & & & & car wash\& gomista & $\begin{array}{l}\text { Partners } \\
\text { hip }\end{array}$ & 2 \\
\hline & & & & Shoeshine & Sole & 10 \\
\hline \multirow[t]{4}{*}{2} & \multirow[t]{4}{*}{ Around old railway rail sides } & \multirow[t]{4}{*}{ Dire Dawa } & & retail trade & Sole & \\
\hline & & & & $\begin{array}{l}\text { magazine reading } \\
\text { centers }\end{array}$ & $\begin{array}{l}\text { Partners } \\
\text { hip }\end{array}$ & 5 \\
\hline & & & & Fast foods & $\begin{array}{l}\text { Partners } \\
\text { hip }\end{array}$ & 10 \\
\hline & & & & Lavajo & $\begin{array}{l}\text { Partners } \\
\text { hip }\end{array}$ & 5 \\
\hline 3 & $\begin{array}{l}\text { A place around the back of dire } \\
\text { mall }\end{array}$ & $\begin{array}{l}\text { Sabian } \\
\text { (madeya) }\end{array}$ & $\begin{array}{l}1 \mathrm{~km} \\
\text { long }\end{array}$ & $\begin{array}{l}\text { retail trade with } \\
\text { different } \\
\text { specialization }\end{array}$ & Sole & 100 \\
\hline 4 & $\begin{array}{l}\text { Around the right of main gate of } \\
\text { Dire-Dawa University. }\end{array}$ & $\begin{array}{l}\text { GTZ } \\
\text { (DDU } \\
\text { main gate) } \\
\end{array}$ & & $\begin{array}{ll}\text { Main } & \text { vegetable } \\
\text { market } & \end{array}$ & Sole & 1000 \\
\hline 5 & $\begin{array}{l}\text { In the compound of Dire Dawa } \\
\text { University. }\end{array}$ & Bewanawe & & urban agriculture & $\begin{array}{l}\text { Corpora } \\
\text { tion }\end{array}$ & 20 \\
\hline \multirow[t]{4}{*}{6} & \multirow[t]{4}{*}{$\begin{array}{l}\text { In the way to main gate of dire } \\
\text { dawa university }\end{array}$} & \multirow[t]{4}{*}{ Bewanawe } & \multirow{4}{*}{$\begin{array}{l}1.5 \\
\mathrm{~km} \\
\text { long }\end{array}$} & book stores & $\begin{array}{l}\text { Partners } \\
\text { hip }\end{array}$ & 1 \\
\hline & & & & $\begin{array}{l}\text { megazin reading } \\
\text { centers }\end{array}$ & $\begin{array}{l}\text { Partners } \\
\text { hip }\end{array}$ & 1 \\
\hline & & & & Stationary shops & Sole & 5 \\
\hline & & & & Shoeshine & Sole & 10 \\
\hline 7 & korentos meda & Betony & & $\begin{array}{ll}\text { Main } & \text { vegetable } \\
\text { market } & \\
\end{array}$ & Sole & 1000 \\
\hline 8 & Tony agricultural research site & Tony & & $\begin{array}{l}\text { recreational } \\
\text { centers }\end{array}$ & $\begin{array}{l}\text { Partners } \\
\text { hip }\end{array}$ & 2 \\
\hline
\end{tabular}




\begin{tabular}{|c|c|c|c|c|c|}
\hline & & & Cafeterias & $\begin{array}{l}\text { Partners } \\
\text { hip }\end{array}$ & 2 \\
\hline \multirow[t]{5}{*}{9} & \multirow[t]{4}{*}{ Teneswa meda } & \multirow[t]{4}{*}{ Sabian } & Cafeterias & $\begin{array}{l}\text { Partners } \\
\text { hip }\end{array}$ & 3 \\
\hline & & & book stores & $\begin{array}{l}\text { Partners } \\
\text { hip }\end{array}$ & 2 \\
\hline & & & Shoeshine & Sole & 20 \\
\hline & & & $\begin{array}{l}\text { magazine reading } \\
\text { centers }\end{array}$ & $\begin{array}{l}\text { Partners } \\
\text { hip }\end{array}$ & 2 \\
\hline & & & Total & & 2300 \\
\hline
\end{tabular}

Source: Questionnaire Survey (2019)

Another sample area is government owned recreation centers, parks and shades. The following table shows some of the areas in administrative district 03 .

Table 12: Job opportunities in idle spaces, shopping sheds and government owned houses DDA, Administrative district

\begin{tabular}{|l|l|l|l|l|l|}
\hline Specific place & Possible jobs & Entities & $\begin{array}{l}\text { No of } \\
\text { entities }\end{array}$ & $\begin{array}{l}\text { Number of } \\
\text { people/entity }\end{array}$ & $\begin{array}{l}\text { Total } \\
\text { number } \\
\text { of } \\
\text { people }\end{array}$ \\
\hline $\begin{array}{l}\text { Millennium park } \\
\text { (kezira ) }\end{array}$ & $\begin{array}{l}\text { photo, video, and related service, event } \\
\text { organizing, recreation center, café and } \\
\text { restaurant }\end{array}$ & Partnerships & 4 & 20 & 80 \\
\hline $\begin{array}{l}\text { Millennium park } \\
\text { (around mayor's } \\
\text { office) }\end{array}$ & $\begin{array}{l}\text { photo, video, and related service, event } \\
\text { organizing, recreation center, café and } \\
\text { restaurant }\end{array}$ & Partnerships & 4 & 20 & 80 \\
\hline $\begin{array}{l}\text { Nations and } \\
\text { nationality park } \\
\text { photo, video, and related service, event } \\
\text { organizing, recreation center, café and } \\
\text { restaurant }\end{array}$ & Partnerships & 4 & 20 & 80 \\
\hline $\begin{array}{l}\text { Child recreation } \\
\text { center near to } \\
\text { conel bridge }\end{array}$ & $\begin{array}{l}\text { Daycare, recreation center, shower, } \\
\text { fast food production }\end{array}$ & Partnerships & 2 & 20 & 40 \\
\hline $\begin{array}{l}\text { Shementeria line } \\
\text { retailing, Retailing shops, fast food } \\
\text { delivery }\end{array}$ & Sole prop. & 20 & 1 & 20 \\
\hline $\begin{array}{l}\text { Shades around } \\
\text { Hamdael }\end{array}$ & Manufacturing building materials & Partnership & 10 & 6 & 60 \\
\hline Total & & & 370 \\
\hline
\end{tabular}

Source: Questionnaire Survey (2019)

According to the above table people may engage in parks, recreation centers, sport fields etc. serving the community with different supplies. There are also multiple houses like Saba bakery in administrative district (kebelle) 06 and mining area in administrative districts 09 and 08. Identifying and optimal utilization of such areas in the 9 Administrative districts may create job for at least 3330 youths.

\section{Conclusion}

In the study area there are 11,891 registered unemployed peoples. Of this 10,141 of them are non-graduates, while the remaining 1,750 are graduated from different higher educations. This implies that one of the factors of production (labor) is available as job seekers but still unemployed. Generally, in the study 11,340 job opportunities are identified for job seekers at the premises of both public and private organizations, through creating linkage and subcontracting with organizations and at free spaces of the study area. More specifically, there are 3170 available job opportunities at the premises of public and private organizations. Also, through creating linkages with the existed MSE, government and private organization, there are more than 1130 job opportunities. In outsourcing and sub-contracting there are job opportunities for 1700 job seekers. Likewise, there are 2670 open positions that job seekers can involve themselves as self employment. Besides, government is also offering attention and budgeting large for youths while they creating job in partnership and/or cooperation. This indicates that there are available of land, capital and enterprise factors of production in the study area.

\section{Recommendation}

So as to executively used the identified and other potential job opportunities in different organizations, areas and centers, the city administration in general and the agency in particular should create relationship with these parties 
and continuously arrange systems that can enable to utilize the available job opportunities for unemployed peoples. They should clearly identify the existing job opportunities like Industry Park and arrange mechanism which enables to help in reducing the unemployment problem. According to this study every job is identified to be executed in a team base. Any kind of business have functional units like finance administration, marketing activities, operations, facility administration, supply chain management etc. therefore the entrepreneurs (job seekers) are going to be organized in a manner they can be dedicated as labor force of their own business entity. Skill, knowledge, creativity, learning and growth, building super effective team and sustainable business entity are factors for sustainability of business organizations. Higher education institutions (Dire Dawa university, TVET colleges, private colleges), existing organizations (manufacturing industries, service rendering organizations like Hotels, air and train transportation) are direct source of knowledge, skill and experiences for new ventures. Therefore, to adjust the trade of between service quality and employment creation these institutions should collectively deliver knowledge and practical experience of enterprise management for new entrepreneurs until the learning stage will over.

\section{References}

Abebe, F. (2012). Unemployment in urban Ethiopia: determinants and impact on household.

Abrham, S., Jose, B., Kebede, B., \& Birhanu, T. (2017). Assessment of Alternative Employment Opportunities in Addis Ababa City Administration, City Government of Addis Ababa Micro \& Small Enterprises' Development Bureau, Addis Ababa, 2017

Adil, H. (2011) Important Theories of Unemployment and Public Policies, Journal of Applied

Central Statistics Agency (2012).'2007 Population and Housing Census of Ethiopia'. Dire Dawa Report, Addis Ababa: Central Statistics Agency, 2012 Report on the Ethiopian economy Vol. V, 2005/2006, 251-281

EEA (Ethiopian Economics Association) (2005/06) Unemployment challenges and prospects, welfare. Ethiopian Journal of Economics, Vol XXI No. 2, October 2012, 127157

FDRE Ministry of Trade and Industry, (1997), Micro and Small Enterprises Development Strategy Addis Ababa: Ministry of Trade and Industry.

Feldstein, M. S. (1997). The Private and Social Costs of Unemployment. Paper presented at the American Economic Association Meeting. Working Paper 223. New York.

Ghanem, H. (2016). Entrepreneurship for Inclusion. In The Arab Spring Five Years Later: Toward Greater Inclusiveness (pp. 88-106). Washington, D.C.: Brookings Institution Press. Retrieved from http://www.jstor.org/stable/10.7864/j.ctt1657tv8.8

Hussmanns, R. (1989). Measurement of employment, unemployment and underemployment -

ILO (2013b) Resolution Concerning Statistics of Work, Employment and Labor International Institute of Social Studies, The Hague, Netherlands International Labor Organization

International Labor Organization. (ILO, 2008). Profile of employment and poverty in Africa: Evidence from Ethiopia, Nigeria, Ghana, Tanzania, Kenya, and Uganda, 2008. ILO publication, East Africa multiDisciplinary Advisory Team (EAMAT).

Jaafar, M., Abdul-Aziz, A., \& Sahari, M. (2009). The use of social network theory on entrepreneur's linkages development. Theoretical and Empirical Researches in Urban Management, 4(1S), 101-119. Retrieved from http://www.jstor.org/stable/24872412

Olsson, O. (2009). Essentials of Advanced Macroeconomic Theory.

Organization for Economic cooperation and Development. (OECD, 2004). Promoting entrepreneurship and innovative small and micro enterprises (SMEs) in global economy: towards a more responsible and inclusive globalization. Istanbul, Turkey. 